\title{
No Correlation between Beta2-Adrenergic Receptor Polymorphisms and the Severity and Clinical Control of Geriatric Asthma and COPD
}

Inderpal Randhawa ${ }^{1}$, Andrew Pham ${ }^{2 *}$, William Klaustermeyer ${ }^{2}$ and Joseph Yusin ${ }^{2}$

${ }^{1}$ Long Beach Memorial-Miller Children's Hospital

${ }^{2}$ VA West Los Angeles Healthcare Center/UCLA, USA

\begin{abstract}
Background: Polymorphisms of the $\beta 2$-adrenergic receptor (ADRB2) have previously been associated with non-specific bronchial hyper-responsiveness, adverse response to $\beta 2$-agonists and variable effects on lung function The objective of this study was to determine whether genotypic variance in ADRB2 polymorphisms in a cohort of geriatric men and women with asthma and/or COPD correlate with disease severity, baseline pulmonary function, and the ability to maintain clinical control of their disease.

Methods: This comparative, prospective cohort study sequenced two ADRB2 polymorphisms, Arg16 --> Gly and GIn27 --> Glu, in 103 geriatric patients with a clinical history of asthma and/or COPD. Primary endpoints included pulmonary exacerbation rate, hospitalization rate, and quality of life scores.

Results: Arg/Arg genotype comprised $13.6 \%$ of the cohort. No significant differences in baseline pulmonary functions were noted across genotypic variants. No significant difference was associated with genotype and change in lung function, exacerbations, clinical hospitalizations, exercise tolerance and subjective quality of life assessment over 6 months of follow-up.
\end{abstract}

Conclusion: We conclude that in a geriatric asthma and/or COPD population, ADRB2 polymorphisms are not a factor in the ability to control disease.

Keywords: Beta2-adrenergic receptor; Polymorphism; Geriatric; Asthma; COPD; Arg16Gly; Gln27Glu

\section{Introduction}

Asthma and Chronic Obstructive Pulmonary Disease (COPD) fall under the category of obstructive lung disease, both characterized physiologically by air flow obstruction. The obstruction in asthma is largely reversible whereas the airflow limitation in COPD tends to be persistent and not fully reversible [1,2]. Overlap between the two conditions exists characterized by airway limitation which does not fully remit in addition to symptoms of chronic bronchitis and emphysema. Similarly, COPD variants may be characterized with airway hyperactivity whose airflow obstruction is partially reversible [2].

Bronchodilators are the mainstay of treatment in both diseases. One type, beta2-agonists, stimulates the beta2-adrenergic receptor increasing cyclic AMP thereby inducing bronchial relaxation [2]. The other principle class of bronchodilators, anti-cholinergics, leads to broncho-dilation via a different mechanism by blocking cholinergic effect on muscarinic receptors [2].

In the last decade, the $\beta_{2}$-adrenergic receptor gene (ADRB2) has been implicated in asthma and obstructive lung disease therapeutic response [3]. ADRB2 is located on chromosome 5q31.32 and encodes the beta2-adrenergic receptor of which a number of Single Nucleotide Polymorphisms (SNPs) exist. Of these, two non-synonymous SNPs have been well characterized, occurring at codon 16 and 27. Position 16 is reflected by a substitution of arginine with glycine whereas at position 27, glutamate is replaced with glutamine.

ADRB2 polymorphism studies on therapeutic response, albuterol use, mortality and disease severity are well published particularly in the pediatric population. The results of such studies on disease risk and treatment response result in conflicting results [3-8]. Specific ADRB2 polymorphisms may be associated with COPD structural lung disease, disease control and drug specific response to therapy [9-14]. Variable ADRB2 study designs have yielded conflicting data in the past decade. Despite specific associations with obstructive lung disease, ADRB2 polymorphisms are not well studied in the geriatric population. Given the severity of obstructive lung disease in this growing demographic, our study sought to examine the role of ADRB2 gene polymorphisms on mixed asthma and COPD disease control in a geriatric population.

\section{Methods}

\section{Study patients}

This study was approved by the University of California Los Angeles, Wadsworth VA Institutional Review Board, and all participants signed informed consent before entering the study. Subjects were randomly enrolled into this comparative, prospective cohort study from a list of asthma or COPD patients who visited the West Los Angeles Veterans Affairs Medical Center Allergy and Immunology clinic. The diagnosis of asthma was made either by an allergist or a pulmonologist, and COPD was diagnosed according to the GOLD guidelines [2].

Enrolled patients were either male or female, $>55$ years of age, either current or ex-smokers with at least one year of clinical follow-up.

*Corresponding author: Andrew Pham, 11301 Wilshire BLVD \#111R Departmen of Allergy and Immunology Los Angeles, CA 90073, USA, Tel: 2022767815; E-mail: andrewqpham@gmail.com

Received May 08, 2014; Accepted October 28, 2014; Published November 04 2014

Citation: Randhawa I, Pham A, Klaustermeyer W, Yusin J (2014) No Correlation between Beta2-Adrenergic Receptor Polymorphisms and the Severity and Clinical Control of Geriatric Asthma and COPD. J Allergy Ther 5: 196. doi:10.4172/21556121.1000196

Copyright: (C) 2014 Randhawa I, et al. This is an open-access article distributed under the terms of the Creative Commons Attribution License, which permits unrestricted use, distribution, and reproduction in any medium, provided the original author and source are credited. 
None of the patients had a respiratory infection or an exacerbation for at least 6 months prior to the study. All patients received standard of care therapy based upon National Asthma Education and Prevention Program (NAEPP) and/or the Global Strategy for the Diagnosis, Management and Prevention of COPD (GOLD) guidelines [2,15]. Primary outcomes included frequency of exacerbations, hospitalization rates, and quality of life scores over 6 months of follow-up.

\section{DNA genotyping}

DNA was obtained from buccal swabs using a sodium hydroxide lysis method, modified as follows. A piece of swab was removed by forceps and soaked in $40 \mathrm{ml}$ of $0.2 \mathrm{M} \mathrm{NaOH}$ at $75.8^{\circ} \mathrm{C}$ for $5 \mathrm{~min}$. Neutralization was completed by adding $360 \mathrm{ml} .04 \mathrm{M}$ Tris, $\mathrm{pH} 7.5$, for a total of $400 \mathrm{ml}$ of genomic DNA. Five microliters of this solution was used as template for PCR amplification. ADRB2 sequences containing the polymorphic bases were amplified by PCR in a 25 $\mathrm{ml}$ reaction containing 1 PCR buffer, $1 \mathrm{U}$ Taq DNA polymerase (Invitrogen, Carlsbad, CA), $1.5 \mathrm{mM} \mathrm{MgCl}, 0.2 \mathrm{mM}$ dNTPs, and each primer at $400 \mathrm{mM}$. Primer sequences were determined as follows: (forward: 5'-GCGGCTTCTTCAGAGCAC-3'; reverse: 5'-CCACCCACCCACACCTCGTCCC- $\left.3^{\prime}\right)$. PCR was amplified under the following conditions: $96.8^{\circ} \mathrm{C}$ for $5 \mathrm{~min}$, followed by 30 cycles of denaturing $\left(96.8^{\circ} \mathrm{C}\right.$ for $\left.30 \mathrm{sec}\right)$, annealing $\left(55.8^{\circ} \mathrm{C}\right.$ for $\left.30 \mathrm{sec}\right)$, and extension $\left(72.8^{\circ} \mathrm{C}\right.$ for $\left.30 \mathrm{sec}\right)$, with a final extension at $72.8^{\circ} \mathrm{C}$ for 6 min. The ADRB2 genotype at codons 16 and 27 were determined from the PCR product using SNaPshot (Applied Biosystems, Inc., Foster City, CA). The genotyping primer sequence for codon 16 is 5'-AAAAAAACCTTCTTGCTGGCACCCAAT-3' and for codon 27 is 5'-AAAAAAAAAAAAAACGGACCACGACGTCACGCA-3'.

\section{Juniper score}

The validated Juniper Score for Asthma was utilized every 3 months during a clinic visit [16]. The 32 question survey was completed by the patient. If the patient was not comfortable or literate to complete the evaluation, a staff member assisted by reading the questions. Research staff ensured completion of each survey prior to data analysis. The scores collected each month were evaluated as a mean (averaged over 3 months). The mean scores were also analyzed annually for quarterly visit variability.

\section{COPD clinical questionnaire}

The validated COPD clinical questionnaire was utilized every 3 months during a clinic visit $[17,18]$. The 10 question survey was completed by the patient. If the patient was not comfortable or literate to complete the evaluation, a staff member assisted by reading the questions. Research staff ensured completion of each survey prior to data analysis. The scores collected each month were evaluated as a mean (averaged over 3 months). The mean scores were also analyzed annually for quarterly visit variability.

\section{Asthma/COPD staging}

All patients underwent pulmonary function testing (body plethysmography) annually with spirometry measurements every 3 months. Patients were staged as intermittent, mild, moderate or severe asthma persistent based upon NAEPP asthma guidelines or COPD stage I-IV based upon GOLD criteria [2,15]. Clinical control of disease state is described in Tables 1 and 2.

\section{Statistical analysis}

Chi square and t-tests were used to examine potential differences

\begin{tabular}{|l|l|l|l|l|}
\hline & $\begin{array}{l}\text { Mild } \\
\text { Intermittent }\end{array}$ & $\begin{array}{l}\text { Mild } \\
\text { Persistent }\end{array}$ & $\begin{array}{l}\text { Moderate } \\
\text { Persistent }\end{array}$ & $\begin{array}{l}\text { Severe } \\
\text { Persistent }\end{array}$ \\
\hline Symptoms & $<2 /$ week & $>2 /$ week & Daily & Continual \\
\hline Night symptoms & $<2 /$ month & $>2 /$ month & $>1 /$ week & Frequent \\
\hline FEV 1 & $>80 \%$ & $\begin{array}{l}>80 \% \\
\text { predicted }\end{array}$ & $60-80 \%$ & $<60 \%$ \\
\hline Peak flow variability & $<20 \%$ & $20-30 \%$ & $>30 \%$ & $>30 \%$ \\
\hline
\end{tabular}

Table 1: Classification of asthma severity [15].

\begin{tabular}{|c|c|}
\hline Stage & Spirometry \\
\hline GOLD 1: Mild & $\mathrm{FEV}_{1} \geq 80 \%$ predicted \\
\hline GOLD 2: Moderate & $50 \% \leq \mathrm{FEV}_{1}<80 \%$ predicted \\
\hline GOLD 3: Severe & $30 \% \leq \mathrm{FEV}_{1}<50 \%$ predicted \\
\hline GOLD 4: Very Severe & $\mathrm{FEV}_{1}<30 \%$ predicted \\
\hline
\end{tabular}

Table 2: COPD Staging [2]

\begin{tabular}{|l|c|c|}
\hline & Frequency & Percent \\
\hline Gender & & \\
\hline Female & 15 & 14.56 \\
\hline Male & 88 & 85.44 \\
\hline Race & & \\
\hline African American & 17 & 16.50 \\
\hline Caucasian & 72 & 69.90 \\
\hline Hispanic & 11 & 10.68 \\
\hline Pacific Islander/Asian & 3 & 2.91 \\
\hline Smoking Status & & \\
\hline Non-Smoker & 92 & 89.32 \\
\hline Smoker & 11 & 10.68 \\
\hline
\end{tabular}

Table 3: Baseline demographics of the study participants.

in patient characteristics by genotypic variance. Impact of genotypic polymorphisms on percent of patients in control of asthma or COPD over total visits was examined and the significance determined by means of chi square tests. Cox regression analysis was applied to evaluate differences in the distribution of duration of clinical control of asthma or COPD vs. genotype subgroups. Significance was assessed by means of the Wald Chi Square test. Analyses were performed using SAS v 8.0.

\section{Results}

The study recruited 116 patients initially. Absent genotype records resulted in 103 enrollees, characterized in Table 3. Mean age was 68.7 with ages ranging between 55 and 92 . The demographic, as expected from the VA population, was predominantly male, with 88 males enrolled in the study (85.4\%). At codon 16, 35.9\% $(\mathrm{n}=37)$ were homozygous for the major ADRB2 allele (Gly/Gly), 50.5\% ( $\mathrm{n}=52)$ were heterozygous (Arg/ Gly), and $13.6 \%(\mathrm{n}=14)$ were homozygous for the minor allele (Arg/ Arg). At position $27,32.0 \%(n=33)$ were homozygous for the major ADRB2 allele $(\mathrm{Gln} / \mathrm{Gln}), 51.5 \%(\mathrm{n}=53)$ were heterozygous $(\mathrm{Gln} / \mathrm{Glu})$, and $16.5 \%(n=17)$ were homozygous for the minor allele $(\mathrm{Glu} / \mathrm{Glu})$. The overall patient characteristics including asthma stage, COPD stage, number of exacerbations, and number of oral steroid versus haplotype are displayed in Table 4. Of note, no combinations of the Arg/Arg and Glu/Glu alleles enrolled in our study population.

\section{Asthma and COPD staging}

Specific polymorphisms and asthma severity staging are displayed in Table 5. No statistical difference in frequency was noted between ADRB2 polymorphism and asthma stage severity ( $\mathrm{p}$-value range 0.9708-0.9947). Specific polymorphisms and COPD severity staging 
Citation: Randhawa I, Pham A, Klaustermeyer W, Yusin J (2014) No Correlation between Beta2-Adrenergic Receptor Polymorphisms and the Severity and Clinical Control of Geriatric Asthma and COPD. J Allergy Ther 5: 196. doi:10.4172/2155-6121.1000196

Page 3 of 6

\begin{tabular}{|c|c|c|c|c|c|c|c|c|}
\hline & GIn/GIn Arg/Arg & GIn/GIn Arg/Gly & GIn/GIn Gly/Gly & GIn/Glu Arg/Arg & GIn/Glu Arg/Gly & GIn/Glu Gly/Gly & Glu/Glu Arg/Gly & Glu/Glu Gly/Gly \\
\hline Participants & 11 & 15 & 7 & 3 & 32 & 18 & 5 & 12 \\
\hline Male & $9(81.82 \%)$ & $14(93.33 \%)$ & $7(100 \%)$ & $3(100 \%)$ & $27(84.38 \%)$ & $13(72.22 \%)$ & $5(100 \%)$ & $10(83.33 \%)$ \\
\hline \multicolumn{9}{|c|}{ Asthma Stage } \\
\hline 1 & $3(27.27 \%)$ & $2(13.13 \%)$ & 0 & 0 & $5(15.63 \%)$ & $1(5.56 \%)$ & 0 & $2(16.67 \%)$ \\
\hline 2 & $2(18.18 \%)$ & $2(13.13 \%)$ & $2(28.57 \%)$ & 0 & $6(18.75 \%)$ & $8(44.44 \%)$ & $3(60 \%)$ & $2(16.67 \%)$ \\
\hline 3 & $5(45.45 \%)$ & $8(53.33 \%)$ & $4(57.14 \%)$ & $1(33.33 \%)$ & $16(50 \%)$ & 7 (38.39\%) & $1(20 \%)$ & $5(41.67 \%)$ \\
\hline 4 & $1(9.09 \%)$ & $3(20 \%)$ & $1(14.29 \%)$ & $2(66.67 \%)$ & $5(15.63 \%)$ & $2(11.11 \%)$ & $1(20 \%)$ & $3(25 \%)$ \\
\hline \multicolumn{9}{|l|}{ COPD Stage } \\
\hline 1 & $4(36.36 \%)$ & $4(26.67 \%)$ & 0 & 0 & $9(28.13 \%)$ & $6(33.33 \%)$ & $2(40 \%)$ & $3(25 \%)$ \\
\hline 2 & $3(27.27 \%)$ & $6(40 \%)$ & $4(57.14 \%)$ & 0 & $14(43.75 \%)$ & $6(33.33 \%)$ & $1(20 \%)$ & $5(41.67 \%)$ \\
\hline 3 & $3(27.27 \%)$ & $4(26.67 \%)$ & $2(28.57 \%)$ & $2(66.67 \%)$ & $6(18.75 \%)$ & $5(27.78 \%)$ & $1(20 \%)$ & $2(16.67 \%)$ \\
\hline 4 & $1(9.09 \%)$ & $1(6.67 \%)$ & $1(14.29 \%)$ & $1(33.33 \%)$ & $3(9.38 \%)$ & $1(5.56 \%)$ & $1(20 \%)$ & $2(16.67 \%)$ \\
\hline \multicolumn{9}{|l|}{ Exacerbation } \\
\hline 0 & $5(45.45 \%)$ & $8(53.33 \%)$ & 0 & 0 & $15(46.88 \%)$ & $3(16.67 \%)$ & $2(40 \%)$ & $5(41.67 \%)$ \\
\hline 1 & $3(27.27 \%)$ & $3(20 \%)$ & $5(71.43 \%)$ & $2(66.67 \%)$ & $11(34.38 \%)$ & $13(72.22 \%)$ & $1(20 \%)$ & $3(25 \%)$ \\
\hline 2 & $1(9.09 \%)$ & $2(13.33 \%)$ & $2(28.57 \%)$ & 0 & $4(12.50 \%)$ & $1(5.56 \%)$ & $1(20 \%)$ & $1(8.33 \%)$ \\
\hline 3 & 0 & $1(6.67 \%)$ & 0 & 0 & 0 & 0 & 0 & $2(16.67 \%)$ \\
\hline 4 & $1(9.09 \%)$ & 0 & 0 & $1(33.33 \%)$ & $1(3.13 \%)$ & $1(5.56 \%)$ & 0 & 0 \\
\hline 5 & 0 & 0 & 0 & 0 & $1(3.13 \%)$ & 0 & 0 & 0 \\
\hline 6 & $1(9.09 \%)$ & 0 & 0 & 0 & 0 & 0 & 0 & 0 \\
\hline 8 & 0 & 0 & 0 & 0 & 0 & 0 & 0 & $1(8.33 \%)$ \\
\hline 12 & 0 & $1(6.67 \%)$ & 0 & 0 & 0 & 0 & $1(20 \%)$ & 0 \\
\hline \multicolumn{9}{|l|}{ Oral Steroid } \\
\hline 0 & $5(45.45 \%)$ & $8(53.33 \%)$ & $1(14.29 \%)$ & 0 & $16(50 \%)$ & $4(22.22 \%)$ & $2(40 \%)$ & $5(41.67 \%)$ \\
\hline 1 & $3(27.27 \%)$ & $3(20 \%)$ & $4(57.14 \%)$ & $2(66.67 \%)$ & $12(37.5 \%)$ & $11(61.11 \%)$ & $1(20 \%)$ & $3(25 \%)$ \\
\hline 2 & $1(9.09 \%)$ & $2(13.13 \%)$ & $1(14.29 \%)$ & 0 & $2(6.25 \%)$ & $2(11.11 \%)$ & $1(20 \%)$ & $1(8.33 \%)$ \\
\hline 3 & $2(18.18 \%)$ & 0 & 0 & 0 & 0 & 0 & 0 & $2(16.67 \%)$ \\
\hline 4 & 0 & 0 & $1(14.29 \%)$ & 0 & $1(3.13 \%)$ & $1(5.56 \%)$ & 0 & 0 \\
\hline 5 & 0 & $1(6.67 \%)$ & 0 & $1(33.33 \%)$ & $1(3.13 \%)$ & 0 & 0 & 0 \\
\hline 8 & 0 & 0 & 0 & 0 & 0 & 0 & 0 & $1(8.33 \%)$ \\
\hline 13 & 0 & 0 & 0 & 0 & 0 & 0 & $1(20 \%)$ & 0 \\
\hline 14 & 0 & $1(6.67 \%)$ & 0 & 0 & 0 & 0 & 0 & 0 \\
\hline
\end{tabular}

Table 4: Statistical summary of the participants, Asthma stage, COPD stage, Exacerbation and Oral Steroid use by genotype (Arg16Gly and Gln27Glu combination).

are displayed in Table 6. No statistical difference in frequency was noted between ADRB2 polymorphism and COPD stage severity (p-value range 0.6843-0.9434). Figures 1 and 2 displays the distribution of specific polymorphisms versus asthma or COPD staging and do not show a significant frequency difference among different genotype groups.

\section{Juniper and COPD clinical questionnaire score}

No statistical difference in frequency was noted between ADRB2 polymorphism and mean Juniper score ( $\mathrm{p}$-value $=0.747)$. Similarly, no statistical difference in frequency was noted between ADRB2 polymorphisms and mean COPD Clinical Questionnaire (p-value range 0.845). Sub-analysis of mean Juniper and COPD Clinical Questionnaire variability during quarterly visits also did not correlate with ADRB2 polymorphism ( $\mathrm{p}$-value $>0.05$ ).

\section{Exacerbations and hospitalizations}

No statistical difference in frequency of exacerbation was noted between ADRB2 polymorphism ( $\mathrm{p}$-value range 0.1319-0.0561). Of note, five patients deemed steroid dependent were excluded from this analysis. No statistical difference in frequency of hospitalization was noted between ADRB2 polymorphisms (p-value range 0.132-0.447).

\section{Discussion}

Asthma and COPD disease modification are focused in recent years on genetic mutations, epigenetics and post-translational modification. The ADRB2 polymorphism remains an area of focus stemming from initial links to asthma morbidity and mortality [19-22]. Associations with specific ADRB2 polymorphisms may predict response to long acting beta agonists (LABA), inhaled corticosteroids (ICS) and anticholinergics [23,24]. Additionally, the COPD population, including geriatric patients, may be susceptible to such predilection based upon recent studies [25]. Alternatively, a number of studies refute such associations [3,26-28]. Given the discrepancy in management required if ADRB2 polymorphisms are implicated, our study uniquely studied the clinical effect of ADRB2 polymorphisms in the most progressive population of obstructive lung disease, geriatrics.

Across all genotypic ADRB2 variants, no statistically significant 


\begin{tabular}{|c|c|c|c|c|c|c|}
\hline & & Stage $1^{a}$ & Stage 2 & Stage 3 & Stage 4 & Total \\
\hline \multirow{12}{*}{ 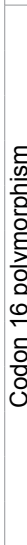 } & Arg/Arg & & & & & \\
\hline & Frequency & 3 & 2 & 6 & 3 & 14 \\
\hline & Percent $^{b}$ & $2.91 \%$ & $1.94 \%$ & $5.83 \%$ & $2.91 \%$ & $13.59 \%$ \\
\hline & Arg/Gly & & & & & \\
\hline & Frequency & 7 & 11 & 25 & 9 & 52 \\
\hline & Percent & $6.80 \%$ & $10.68 \%$ & $24.27 \%$ & $8.74 \%$ & $50.49 \%$ \\
\hline & Gly/Gly & & & & & \\
\hline & Frequency & 3 & 12 & 16 & 6 & 37 \\
\hline & Percent & $2.91 \%$ & $11.65 \%$ & $15.53 \%$ & $5.83 \%$ & $35.92 \%$ \\
\hline & Total & & & & & \\
\hline & Frequency & 13 & 25 & 47 & 18 & 103 \\
\hline & Percent & $12.62 \%$ & $24.27 \%$ & $45.63 \%$ & $17.48 \%$ & $100.00 \%$ \\
\hline \multirow{12}{*}{ 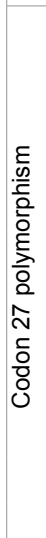 } & Gln/Gln & & & & & \\
\hline & Frequency & 5 & 6 & 17 & 5 & 33 \\
\hline & Percent & $4.85 \%$ & $5.83 \%$ & $16.50 \%$ & $4.85 \%$ & $32.04 \%$ \\
\hline & GIn/Glu & & & & & \\
\hline & Frequency & 6 & 14 & 24 & 9 & 53 \\
\hline & Percent & $5.83 \%$ & $13.59 \%$ & $23.30 \%$ & $8.74 \%$ & $51.46 \%$ \\
\hline & Glu/Glu & & & & & \\
\hline & Frequency & 2 & 5 & 6 & 4 & 17 \\
\hline & Percent & $1.94 \%$ & $4.85 \%$ & $5.83 \%$ & $3.88 \%$ & $16.50 \%$ \\
\hline & Total & & & & & \\
\hline & Frequency & 13 & 25 & 47 & 18 & 103 \\
\hline & Percent & $12.62 \%$ & $24.27 \%$ & $45.63 \%$ & $17.48 \%$ & $100.00 \%$ \\
\hline
\end{tabular}

aStage 1-4 corresponds to mild intermittent, mild persistent, moderate persistent, and severe persistent

bDerived from frequency divided by total number of subjects (103). e.g., Arg/Arg Stage $1: 3 / 103=2.91 \%$

Table 5: Distribution of codon 16 and codon 27 polymorphisms by asthma stage.

differences in baseline pulmonary function were noted. Standardized objective clinical outcomes in lung disease included both objective criteria of staging, disease variability, hospitalizations, and exacerbation rate. No statistically significant difference was observed with objective clinical outcomes and ADRB2 polymorphisms. Similarly, the subjective validation of clinical asthma and COPD was studied utilizing validated survey tools. Again, no statistically significant difference was noted between the Juniper Score for asthma and the COPD Clinical Questionnaire score for COPD and ADRB2 polymorphisms.

The results of our study are supported by prior authors in both genetic and clinical disease state. Migita and colleagues demonstrated the presence of ADRB2 polymorphisms did not increase the risk of asthma development in families [8]. Similarly, a lack of Arg 16 allele and Gln 27 allele polymorphism frequency was noted in two COPD cohorts, Vacca et al. and Joos et al. [11,29]. A meta-analysis performed by Niu and colleagues examining twelve case-control studies and eight cross-sectional studies further confirmed polymorphisms of ADRB2 at positions 16 and 27 did not change the risk of COPD [30]. Functional studies support the modifying role of ADRB2 polymorphismsin response to $\beta 2$-agonists, $\beta 2$-receptor down-regulation, and potential for disease severity [31-33]. Despite purported risk of specific polymorphisms, numerous studies have refuted such findings. Bleecker et al. revealed patients with ADRB2 polymorphisms showed equal response clinically to salmeterol, fluticasone, budesonide and formoterol in asthmatics

$[3,5]$. Yelensky and colleagues noted similar findings in COPD patients treated with indacaterol [26]. Overall, our study demonstrated no clinical risk differential between ADRB2 genotypes and treatment of COPD and asthma in a geriatric population. Given the severity and progression of obstructive lung disease in this patient population, our findings suggest the role of ADRB2 polymorphisms in adult COPD and asthma is minimal. Nonetheless, specific, isolated clinical cases may be present in younger populations.

There are some limitations to the present study. Our study results were based on a small sample size and a predominantly male population. Though determination of clinical control was measured through the primary endpoints of number of exacerbations, hospitalization rates, and quality of life questionnaire scores, change in $\mathrm{FEV}_{1}\left(\right.$ delta $\mathrm{FEV}_{1}$ ) was briefly reviewed and showed no association between genotype and change in lung function. Finally, we did not examine specific treatment regimens in the recruited patients. The relationship between ADRB2 polymorphism and different treatment regimens has been well studied during the last decade with mixed results [3-6,10,24-28]. As such, there has been no major paradigm shift in treatment of asthma or COPD with respect to varying ADRB2 polymorphisms. Considering the prevalence of asthma and COPD is highest in the geriatric population, the goal of this study was to determine the association between markers of asthma and COPD severity with ADRB2 polymorphisms in a cohort of patients 55 years and older.

In conclusion, our findings demonstrate beta2-adrenergic receptor polymorphisms do not correlate with disease severity and clinical

\begin{tabular}{|c|c|c|c|c|c|c|}
\hline & & Stage $1^{a}$ & Stage 2 & Stage 3 & Stage 4 & Total \\
\hline \multirow{12}{*}{ 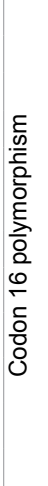 } & Arg/Arg & & & & & \\
\hline & Frequency & 4 & 3 & 5 & 2 & 14 \\
\hline & Percent $^{\mathrm{b}}$ & $3.88 \%$ & $2.91 \%$ & $4.85 \%$ & $1.94 \%$ & $13.59 \%$ \\
\hline & Arg/Gly & & & & & \\
\hline & Frequency & 15 & 21 & 11 & 5 & 52 \\
\hline & Percent & $14.56 \%$ & $20.39 \%$ & $10.68 \%$ & $4.85 \%$ & $50.49 \%$ \\
\hline & Gly/Gly & & & & & \\
\hline & Frequency & 9 & 15 & 9 & 4 & 37 \\
\hline & Percent & $8.74 \%$ & $14.56 \%$ & $8.74 \%$ & $3.88 \%$ & $35.92 \%$ \\
\hline & Total & & & & & \\
\hline & Frequency & 28 & 39 & 25 & 11 & 103 \\
\hline & Percent & $27.18 \%$ & $37.86 \%$ & $24.27 \%$ & $10.68 \%$ & $100.00 \%$ \\
\hline \multirow{12}{*}{ 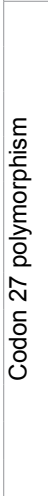 } & GIn/GIn & & & & & \\
\hline & Frequency & 8 & 13 & 9 & 3 & 33 \\
\hline & Percent & $7.77 \%$ & $12.62 \%$ & $8.74 \%$ & $2.91 \%$ & $32.04 \%$ \\
\hline & GIn/Glu & & & & & \\
\hline & Frequency & 15 & 20 & 13 & 5 & 53 \\
\hline & Percent & $14.56 \%$ & $19.42 \%$ & $12.62 \%$ & $4.85 \%$ & $51.46 \%$ \\
\hline & Glu/Glu & & & & & \\
\hline & Frequency & 5 & 6 & 3 & 3 & 17 \\
\hline & Percent & $4.85 \%$ & $5.83 \%$ & $2.91 \%$ & $2.91 \%$ & $16.50 \%$ \\
\hline & Total & & & & & \\
\hline & Frequency & 28 & 39 & 25 & 11 & 103 \\
\hline & Percent & $27.18 \%$ & $37.86 \%$ & $24.27 \%$ & $10.68 \%$ & $100.00 \%$ \\
\hline
\end{tabular}

aStage 1-4 corresponds to GOLD COPD Stage I-IV

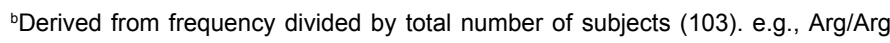
Stage 1: $4 / 103=3.88 \%$

Table 6: Distribution of codon 16 and codon 27 polymorphisms by COPD stage. 


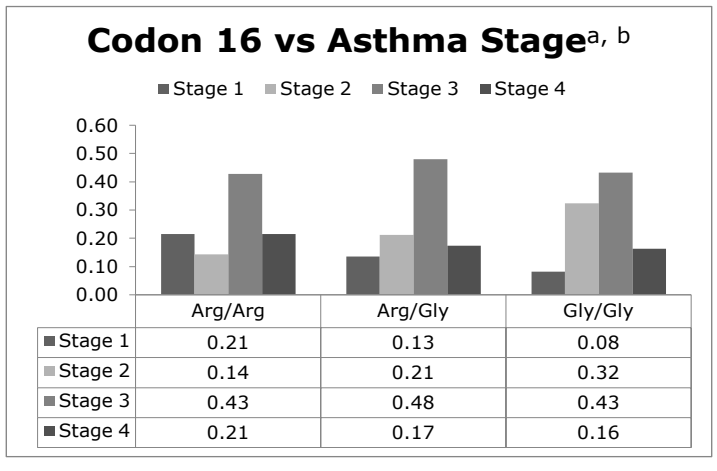

\section{Codon 27 vs Asthma Stage}

-Stage $1 \backsim$ Stage $2 \backsim$ Stage $3 \backsim$ Stage 4

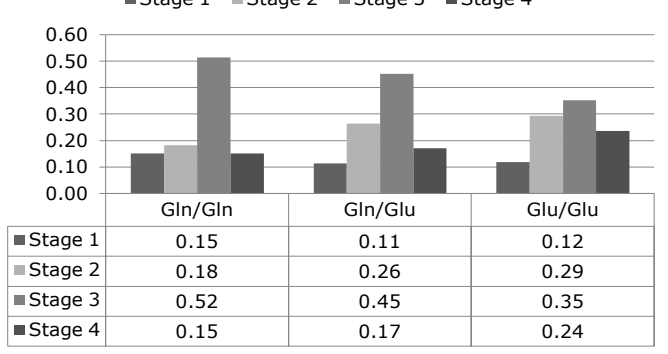

aStage 1-4 corresponds to mild intermittent, mild persistent, moderate persistent, and severe persistent

bNumerical values derived from total patients within an asthma stage with a certain genotype divided by total subjects with that genotype. e.g., Arg/Arg Stage 1: $3 \mathrm{Arg} / \mathrm{Arg}$ subjects classified as Stage 1 out of a total of 14 subjects with the Arg/Arg genotype.

Figure 1: Distribution of different genotype groups by Asthma Stage.
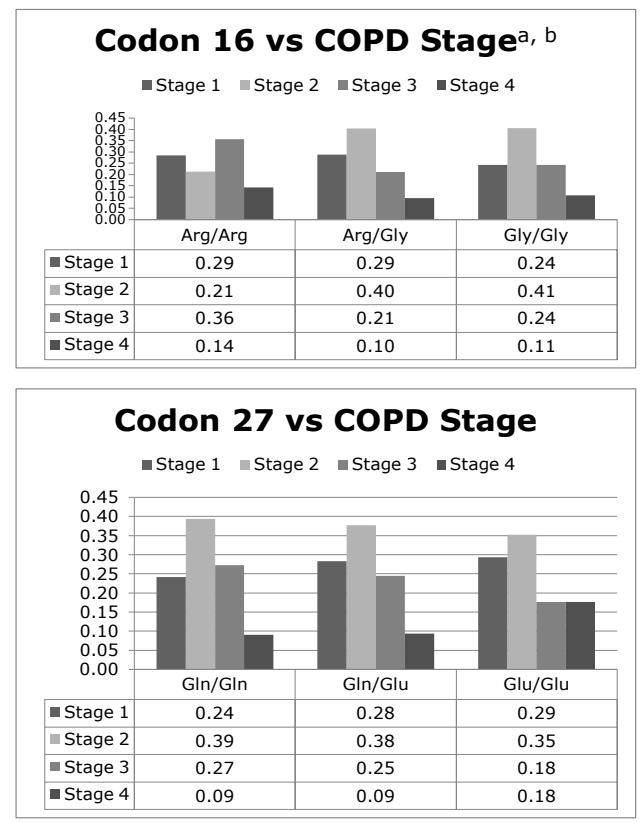

aStage 1-4 corresponds to GOLD COPD Stage I-IV

${ }^{b}$ Numerical values derived from total patients within a COPD stage with a certain genotype divided by total subjects with that genotype. e.g., Arg/Arg Stage 1: 4 Arg/Arg subjects classified as Stage 1 out of a total of 14 subjects with the Arg/Arg genotype.

Figure 2: Distribution of different genotype groups by COPD Stage. control of geriatric patients with asthma and COPD. However, we did not have a significant number of active smoker patients, 11 patients (10.68\%). Additionally, we did not assess second hand smoke exposure in our patient population. Environmental exposures such as smoking or second hand smoking are known epigenetic modifiers via DNA methylation [34-35]. Epigenetic changes can additionally be affected by diet and aging [36-37]. A recent study, examining twins using high resolution computer tomography (HRCT), also demonstrated lung parenchymal and small airway changes were associated with a heritable background [38]. The immune system, cellular function, and phenotype of asthma/COPD may change with age and indeed affect ADRB2 function. Further research is needed to study the epigenetic effects in asthma and COPD. Hence, as further epigenetics on aging, cellular immunity, regulatory $\mathrm{T}$ cell $\left(\mathrm{T}_{\mathrm{reg}}\right)$ function and lung epithelia are discovered, the conclusion of no effect may indeed be incorrect.

\section{Authors' Contributions}

WK along with IR designed the research study and collected and analyzed data. AP, IR, and JY drafted the manuscript. All authors read and approved the final manuscript.

\section{References}

1. Global Strategy for Asthma Management and Prevention, Global Initiative for Asthma (GINA).

2. Global Strategy for the Diagnosis, Management and Prevention of COPD, Global Initiative for Chronic Obstructive Lung Disease (GOLD).

3. Bleecker ER, Nelson HS, Kraft M, Corren J, Meyers DA, et al. (2010) Beta2 receptor polymorphisms in patients receiving salmeterol with or without fluticasone propionate. Am J Respir Crit Care Med 181: 676-687.

4. Bleecker ER, Yancey SW, Baitinger LA, Edwards LD, Klotsman M, et al. (2006) Salmeterol response is not affected by beta2-adrenergic receptor genotype in subjects with persistent asthma. J Allergy Clin Immunol 118: 809-816.

5. Bleecker ER, Postma DS, Lawrance RM, Meyers DA, Ambrose HJ, et al. (2007) Effect of ADRB2 polymorphisms on response to longacting beta2-agonist therapy: a pharmacogenetic analysis of two randomised studies. Lancet 370 : 2118-2125.

6. Basu K, Palmer CN, Tavendale R, Lipworth BJ, Mukhopadhyay S (2009) Adrenergic beta(2)-receptor genotype predisposes to exacerbations in steroidtreated asthmatic patients taking frequent albuterol or salmeterol. J Allergy Clin Immunol 124: 1188-1194.

7. Wilson AM, Gray RD, Hall IP, Lipworth BJ (2006) The effect of beta2adrenoceptor haplotypes on bronchial hyper-responsiveness in patients with asthma. Allergy 61: 254-259.

8. Migita O, Noguchi E, Jian Z, Shibasaki M, Migita T, et al. (2004) ADRB2 polymorphisms and asthma susceptibility: transmission disequilibrium test and meta-analysis. Int Arch Allergy Immunol 134: 150-157.

9. Papatheodorou A, Makrythanasis $P$, Kaliakatsos M, Dimakou A, Orfanidou (2010) Development of novel microarray methodology for the study of mutations in the SERPINA1 and ADRB2 genes-Their association with Obstructive Pulmonary Disease and Disseminated Bronchiectasis in Greek patients. Clin Biochem 43: 43-50.

10. Umeda N, Yoshikawa T, Kanazawa H, Hirata K, Fujimoto S (2008) Association of beta2-adrenoreceptor genotypes with bronchodilatory effect of tiotropium in COPD. Respirology 13: 346-352.

11. Vacca G, Schwabe K, Dück R, Hlawa HP Westphal A et al. (2009) Polymorphisms of the beta2 adrenoreceptor gene in chronic obstructive pulmonary disease. Ther Adv Respir Dis 3: 3-10.

12. Konno S, Makita H, Hasegawa M, Nasuhara Y, Nagai K (2011) Beta2-adrenergic receptor polymorphisms as a determinant of preferential bronchodilator response to $\beta 2$-agonist and anticholinergic agents in Japanese patients with chronic obstructive pulmonary disease. Pharmacogenet Genomics 21: 687-693.

13. Kim WJ, Oh YM, Sung J, Lee YK, Seo JB, et al. (2009) CT scanning-based phenotypes vary with ADRB2 polymorphisms in chronic obstructive pulmonary disease. Respir Med 103: 98-103. 
Citation: Randhawa I, Pham A, Klaustermeyer W, Yusin J (2014) No Correlation between Beta2-Adrenergic Receptor Polymorphisms and the Severity and Clinical Control of Geriatric Asthma and COPD. J Allergy Ther 5: 196. doi:10.4172/2155-6121.1000196

Page 6 of 6

14. Matheson MC, Ellis JA, Raven J, Johns DP, Walters EH, et al. (2006) Beta2 adrenergic receptor polymorphisms are associated with asthma and COPD in adults. J Hum Genet 51: 943-951.

15. Expert Panel Report 3: Guidelines for the Diagnosis and Management of Asthma.

16. Juniper EF, Guyatt GH, Epstein RS, Ferrie PJ, Jaeschke R, et al. (1992) Evaluation of impairment of health related quality of life in asthma: development of a questionnaire for use in clinical trials. Thorax 47: 76-83.

17. van der Molen T, Willemse BW, Schokker S, ten Hacken NH, Postma DS, et al. (2003) Development, validity and responsiveness of the Clinical COPD Questionnaire. Health Qual Life Outcomes 1: 13

18. Kooi HH, Tuinenga MG, Schokker S, Molen T (2003) How to measure Clinical Control in Patients with COPD: the Development of the Clinical COPD Questionnaire (CCQ). QoL Newsletter 31: 9-11.

19. Rebordosa C, Kogevinas M, Guerra S, Castro-Giner F, Jarvis D, et al. (2011) ADRB2 Gly16Arg polymorphism, asthma control and lung function decline. Eur Respir J 38: 1029-1035.

20. Reihsaus E, Innis M, Maclntyre N, Liggett SB (1993) Mutations in the gene encoding for the beta 2-adrenergic receptor in normal and asthmatic subjects. Am J Respir Cell Mol Biol 8: 334-339.

21. Turki J, Pak J, Green SA, Martin RJ, Liggett SB (1995) Genetic polymorphisms of the beta 2-adrenergic receptor in nocturnal and nonnocturnal asthma Evidence that Gly16 correlates with the nocturnal phenotype. J Clin Invest 95: 1635-1641.

22. Holloway JW, Dunbar PR, Riley GA, Sawyer GM, Fitzharris PF, et al. (2000) Association of beta2-adrenergic receptor polymorphisms with severe asthma. Clin Exp Allergy 30: 1097-1103

23. Wechsler ME, Kunselman SJ, Chinchilli VM, Bleecker E, Boushey HA (2009) Effect of $B 2$-adrenergic receptor polymorphism on response to longacting B2 agonist in asthma (LARGE trial): a genotype-stratified, randomised, placebocontrolled, crossover trial. Lancet 374: 1754-1764.

24. Asano K, Yamada-Yamasawa W, Kudoh H, Matsuzaki T, Nakajima T (2010) Association between B-adrenoceptor gene polymorphisms and relative response to B2-agonists and anticholinergic drugs in Japanese asthmatic patients. Respirology 15: 849-854.

25. Hizawa N, Makita H, Nasuhara Y, Betsuyaku T, Itoh Y, et al. (2007) Beta2adrenergic receptor genetic polymorphisms and short-term bronchodilator responses in patients with COPD. Chest 132: 1485-1492.

26. Yelensky R, Li Y, Lewitzky S, Leroy E, Hurwitz C, et al. (2012)A pharmacogenetic study of ADRB2 polymorphisms and indacaterol response in COPD patients. Pharmacogenomics J 12: 484-488.

27. Taylor DR, Epton MJ, Kennedy MA, Smith AD, Iles S, et al. (2005) Bronchodilator response in relation to beta2-adrenoceptor haplotype in patients with asthma. Am J Respir Crit Care Med 172: 700-703.

28. Kim WJ, Oh YM, Sung J, Kim TH, Huh JW (2008) Lung Function Response to 12-week Treatment with Combined Inhalation of Long-acting $\beta 2$ Agonist and Glucocorticoid Acccording to ADRB2 Polymorphism in Patient with Chronic Obstructive Pulmonary Disease. Lung 186: 381-386.

29. Joos L, Weir TD, Connett JE, Anthonisen NR, Woods R, et al. (2003) Polymorphisms in the beta2 adrenergic receptor and bronchodilator response, bronchial hyperresponsiveness, and rate of decline in lung function in smokers. Thorax 58: 703-707.

30. Niu LM, Liang Y, Xu M, Zhang YY, Zhang Y, et al. (2012) Effect of polymorphisms in the $\beta 2$-adrenergic receptor on the susceptibility and pulmonary function of patients with chronic obstructive pulmonary disease: a meta analysis. Chin Med J 125: 2213-2218

31. Green SA, Cole G, Jacinto M, Innis M, Liggett SB (1993) A polymorphism of the human beta 2-adrenergic receptor within the fourth transmembrane domain alters ligand binding and functional properties of the receptor. J Biol Chem 268: 23116-23121.

32. Green SA, Turki J, Bejarano P, Hall IP, Liggett SB (1995) Influence of beta 2-adrenergic receptor genotypes on signal transduction in human airway smooth muscle cells. Am J Respir Cell Mol Biol 13: 25-33.

33. Syamsu, Yusuf I, Budu, Patellongi I (2007) The effect of polymorphism of the beta-2 adrenergic receptor on the response to beta-2 agonist in bronchial asthma patients. Acta Med Indones 39: 8-12.

34. Breton CV, Byun HM, Wenten M, Pan F, Yang A, et al. (2009) Prenatal tobacco smoke exposure affects global and gene-specific DNA methylation. Am J Respir Crit Care Med 180: 462-467.

35. Runyon RS, Cachola LM, Rajeshuni N, Hunter T, Garcia M, et al. (2012) Asthma discordance in twins is linked to epigenetic modifications of $T$ cells. PLoS One 7: e48796.

36. Waterland RA, Jirtle RL (2003) Transposable elements: targets for early nutritional effects on epigenetic gene regulation. Mol Cell Biol 23: 5293-5300.

37. Baccarelli A, Wright RO, Bollati V, Tarantini L, Litonjua AA, et al. (2009) Rapid DNA methylation changes after exposure to traffic particles. Am J Respir Crit Care Med 179: 572-578.

38. Tarnoki DL, Tarnoki AD, Lazar Z, Korom C, Berczi V, et al. (2014) A possible genetic influence in parenchyma and small airway changes in COPD: a pilot study of twins using HRCT. Acta Physiol Hung 101: 167-175. 